\title{
TRANSFORMATION OF CAMPING INTO GLAMPING - TRENDS AND PERSPECTIVES
}

\author{
Ines Milohnić \\ Josipa Cvelić Bonifačić \\ Ivana Licul
}

https://doi.org/10.20867/tosee.05.30

\begin{abstract}
Purpose - This paper explores trends and the perspectives of business stakeholders - camping managers and equipment producers as well as guests - with regard to glamping as the transformation process of camping.

Methodology - To research the transformation of camping into glamping, a survey of the opinions of experts in camping and glamping was conducted in October 2018 and a survey of guests, in the spring of 2018. Responses were collected from 120 campsite managers and 30 camping \& glamping equipment producers from the region. Furthermore, through special online and onsite questionnaires, 130 responses were collected from camping guests.

Findings - This research proves that all the groups consider glamping as the future of camping and foresee an increase in future demand for glamping accommodation. All three groups are fully unanimous in the opinion that the transformation of camping into glamping through the implementation of new and innovative accommodation in camping will contribute to the competitiveness of campsites and holiday parks.

Contribution - The research makes a contribution to theory by broadening the literature in the field of trends and competitiveness in glamping by including the perspectives of managers, producers and guests. The applicable value is seen in the evidence on the importance of implementing innovative accommodation in camping, which contributes to the transformation of camping into glamping - camping that is rejuvenated and redesigned and more competitive than classical camping. For the target groups of managers and producers, this new trend is the basis for strategical planning of future investments and for guests it is a new and exciting way of holiday-making. Keywords camping, glamping, innovative accommodation, trends, competitiveness
\end{abstract}

\section{INTRODUCTION}

Camping in the twenty-first century is strongly marked by new trends in the development of accommodation in campsites, foremost by new demand that combines wishing to stay in the outdoors and wanting all the comforts of home. The popularity of glamping, particularly among the younger generations, is driving the overall transformation of classical camping into glamping, with numerous implications for the general competitiveness of the sector.

This paper investigates the characteristics of glamping from the perspectives of different interest groups: campsite managers, the manufacturers of glamping and camping equipment, and campsite guests. By studying their attitudes and opinions concerning the types of accommodation considered to belong to glamping, the trends in the development of glamping equipment and glamping accommodation, and the key features of modern 
ToSEE - Tourism in Southern and Eastern Europe, Vol. 5, pp. 457-473, 2019

I. Milohnić, J. Cvelić Bonifačić, I. Licul: TRANSFORMATION OF CAMPING INTO GLAMPING - ...

glamping services, the paper identifies the strategic goals of glamping service management and proposes models for further development.

The paper seeks answers to questions regarding the innovative forms of accommodation units in campsite that can considered to be glamping, the attitudes of respondents concerning trends in campsite accommodation development, and the key characteristics of glamping accommodation that are now the trend. The paper also explores which sets of guests are seen as being crucial to glamping service development. Research results show what trends are present in the transformation of camping into glamping, which age groups will make up the key demand for this type of service and what will be the main characteristics of glamping services in the future.

\section{TRANSFORMATION OF CAMPING THROUGH INNOVATIVE ACCOMMODATION IN CAMPSITES IN CROATIA}

For more than a decade, glamping, a sub-form of camping, has been a subject of interest for new generations of campers and a symbol of the magical redesign of overall camping services. The term "glamping" has become synonymous with overall campsite accommodation that, as a rule, is not the property of campers but campsites. Glamping has established itself as a response to numerous factors of new demand: the need for escapism, rest, relaxation and personal wellness; curiosity about new types of accommodation, and the desire for adventure and for developing new social relationships. "Push factors are internal motives, instigated by needs for escapism, rest, relaxation, personal wellness, curiosity, adventure and social interaction" (Brooker and Joppe 2013, 2).

\subsection{Defining "glamping"}

A search for the definition of glamping and for the types and characteristics of accommodation facilities that can be considered glamping facilities reveals a variety of different opinions. According to the Oxford Dictionary, "glamping" is a form of camping that involves accommodation, facilities and services that are more luxurious than those traditionally associated with camping (Oxford Dictionary 2018). In the German language the English term "glamping" coined from the words "glamorous" and "camping", is also used and is explained as a trend for nature lovers who want tents with a touch of luxury ("eine Abkürzung für 'glamouröses Camping' - wird der Trend für wohlhabende Naturfreunde bezeichnet: Zelten mit Luxus-Touch" (DWDS 2018). The German portal Glampings lists the features of glamping as comfortable stay, luxury, time-saving, peace, relaxation and rest (Glampings 2018).

In recent years, glamping has begun to bring together the best of camping and the best of the hotel industry (Glamping Hub 2012). Glamping experiences have encouraged many entrepreneurs to seek new ways of doing an "extreme makeover to the campsites through glamping" (Carter 2011) and to choose glamping as a competitive strategy for their further development. Often referred to as "nature on a silver plate" (Leci Sakačova 2013) or "where nature meets luxury" (Rogers 2011), glamping marks a new chapter in 
ToSEE - Tourism in Southern and Eastern Europe, Vol. 5, pp. 457-473, 2019

I. Milohnić, J. Cvelić Bonifačić, I. Licul: TRANSFORMATION OF CAMPING INTO GLAMPING - ...

tourism development by combining the best achievements of the hotel industry and camping, and merging a stay in the outdoors with top-level amenities.

The new millennium, with its changed perception of the environment, has signalled the big comeback of camping, a kind of return to "posh" roots; but this time, the comeback is all about innovative and creative accommodation in campsites. So, the term "glamping" has not yet reached the age of majority. According to Google Trends (Google Search 2019), the keyword first started being searched on Google in early 2004. The searches were the most saturated in Ireland and the United Kingdom. Since then, glamping accommodations have sprouted up around the world, providing travellers the opportunity to live among, without exactly being one with, nature. "A 2008 NY Times article introducing the concept of glamping explains that the new term being used for upscale - or glamorous - camping could be your ideal green vacation" (Colin 2008).

\subsection{Rapid development of glamping worldwide}

The financial crisis of the first decade of the new millennium further affected the creative development of luxury accommodation that did not necessarily have to be connected to travelling abroad. Value for money became more important and the staycation trend started (Glamping Association 2018). The main philosophy behind glamping has remained the same: sustainable, quasi-outdoor lodging that offers travellers unique, but comfortable, experiences in nature (World Toddler 2016). Millennials (born between 1980 and 2000) have given strong support to the development of glamping holidays. These young urban professionals have embraced glamping breaks as a way to differentiate themselves from their parents' generation through new experiences. When on holiday, Millennials enjoy sharing their glamping experiences via social media.

The fast development of glamping over the past two decades can be seen all over Europe but especially in Great Britain (The Guardian 2010). Glamping is widely popular in France as well as in most of the other Mediterranean countries. Leading Campings of Europe, a group of the 39 best campsites in Europe, promotes camping, glamping and luxury accommodation (Leading Campings of Europe, 2018). In the USA, the popularity of nature escape as a social benefit has become increasingly popular. The American Camping Report states that camping continues to be one of the simplest and most rewarding forms of recreation for connecting with family and friends on a human level (American Camping Report, 2014). Nowadays, more and more campsites, like the KOA campsites, are offering innovative accommodation (Kampgrounds of America 2019). The 2018 American Camping Report provides an overview of the use of accommodation in campsites which shows that among new campers the use of cabins has grown from $20 \%$ in 2012 to $25 \%$ (Kampgrounds of America 2018).

Camping and glamping, in particular, as options for holiday makers have also become very popular in Germany. In 2017 it was estimated that 3 million Germans would go camping and a further 4 million would make shorter camping vacations in Germany (Lohman, Schmucker and Sonntag 2017). Every fourth German appreciates individuality and the privacy of their own apartment or holiday home and every eighth wants to spend their holidays in some type of campsite accommodation (caravan, motorhome, tent or mobile home) (Zwingenberger 2017). 
ToSEE - Tourism in Southern and Eastern Europe, Vol. 5, pp. 457-473, 2019

I. Milohnić, J. Cvelić Bonifačić, I. Licul: TRANSFORMATION OF CAMPING INTO GLAMPING - ...

Slovenia is a country that has developed a huge glamping product in the past decade. The tourism strategy of the government was to support innovation in tourism and in 2004 it began to reward innovation schemes. Later the Bank of Tourism Potential of Slovenia was founded. In 2011 the innovation reward went to Glamping Eco Village (Križaj and Zakonjšek 2011). In the last decade many high-quality glamping resorts and villages have been developed in Slovenia (Charming Slovenia 2018) such as Garden Village Bled, (Garden Village Bled 2018), Herbal Glamping Ljubno (www.avtokampi.si 2015), Adria Village Olimia (Terme Olimia 2018) and Chateau Ramšak (Chateau Ramšak 2018).

The fundamental features of glamping have remained unchanged in the past 15 years; glamping remains a sustainable, quasi-outdoor lodging that offers travellers unique, but comfortable, experiences in nature (World Toddler 2016). Glamping has today become a worldwide phenomenon. The Glamping Association of America was founded in 2018 (American Glamping Association 2018) and a Global Glamping Summit is held annually in the USA and the UK, bringing together everyone interested in developing the glamping business. The glamping business is also encouraged by many websites and online magazines (Inspired camping 2017) and there are also online courses for beginners.

Big tour operators are following this trend offering more and more accommodation in glamping (Vacansselect 2018). Many of them regularly explain to their guests what glamping is all about. For example, Suncamp describes it as "the comfort of a hotel combined with the natural surroundings and the freedom of a campsite" (Suncamp Holidays 2019). Almost daily, new online travel agencies that offer glamping accommodation among other things are emerging in the market. The largest travel agency, www.booking.com, enables searches by type of accommodation and specifies a special category called "Glamping" that in Great Britain alone offers 527 accommodation facilities (Booking.com 1996-2019). The largest portals for the online booking of glamping accommodations, such as www.glamping.com and www.glumpinghub.com, also continue to grow. The first Dutch portal for glamping accommodation in Europe explains that online travel agencies are presenting glamping as a new form of vacationing that implies organised and standardised accommodation that can be sold online (Glamping Europa 2019).

Today, glamping is also seen as experimental tourism and as a way to learn about the world through so-called experimental travel that implies "an authentic way to experience the world" (Glamping.com 2017). With the glamping economy growing stronger by the day, education and consulting systems are being developed (Inspired Camping, 2018). The number of accommodation units that can be referred to as glamping is steadily growing in Europe, as demonstrated by data in the ADAC Camping Guides over the years. 
ToSEE - Tourism in Southern and Eastern Europe, Vol. 5, pp. 457-473, 2019

I. Milohnić, J. Cvelić Bonifačić, I. Licul: TRANSFORMATION OF CAMPING INTO GLAMPING - ...

\section{Graph 1: Average number of accommodation units per campsite by country and} year in Europe

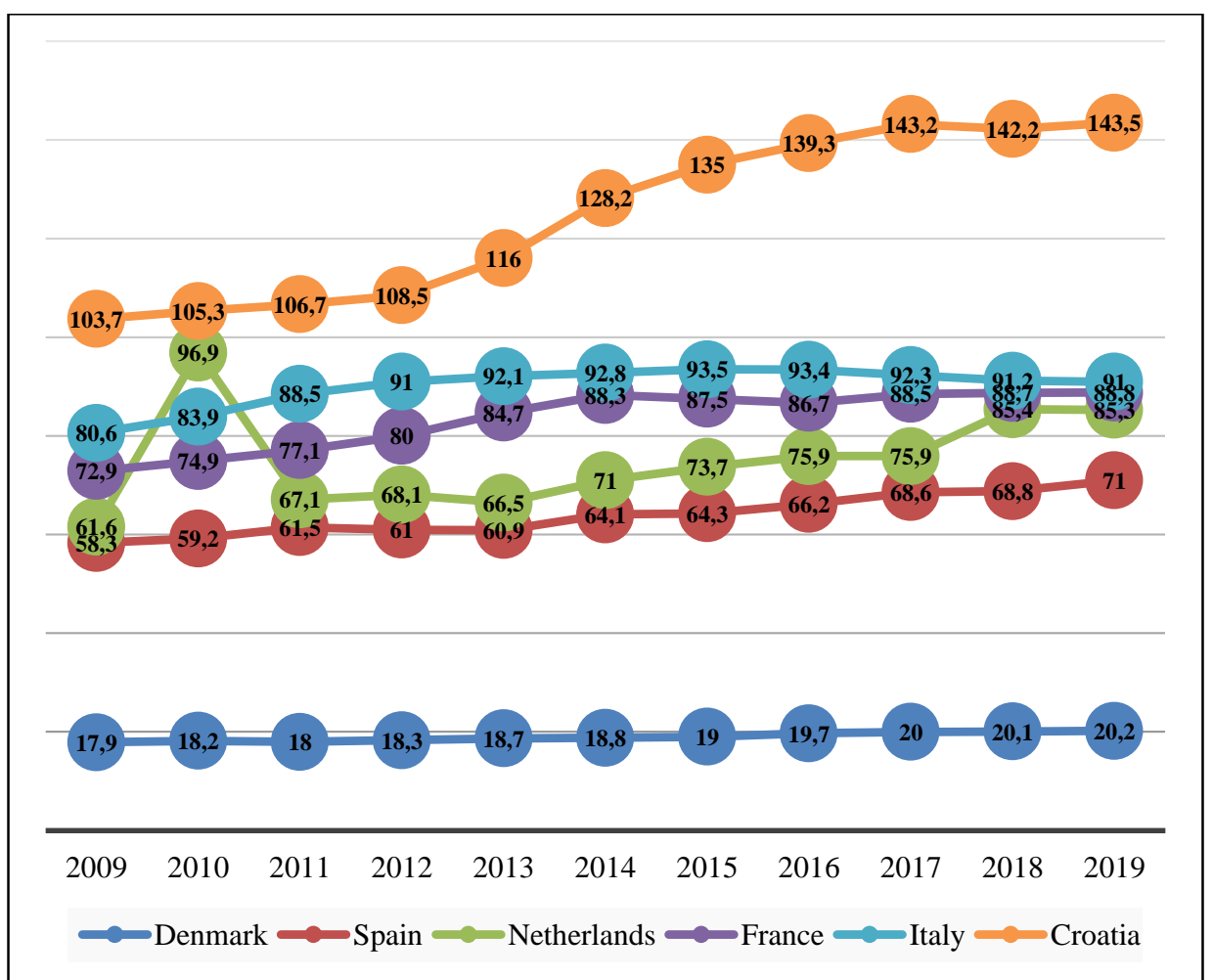

Source: ADAC Camping Guide, Medien und Reise GMBH, Muenchen, February 2019.

As illustrated in the above graph, the number of accommodation units in campsites has grown substantially in all major European camping markets. Croatia shows the fastest growth in the period 2009 - 2019 and in 2019 Croatian campsites comprised on average 144 accommodation units. This gives good reason for using the example of Croatia to study the transformation of campsites through accommodation units.

\subsection{Development of glamping in Croatia}

The development of campsites in Croatia began with mobile homes in campsites. Mobile homes are the latest in a line of innovative products of mobile camping equipment (after tents, trailers and campervans) and the most comfortable yet still mobile type of accommodation in campsites. According to the Ordinance (Official Gazette 2016) mobile homes belong to the category of mobile camping equipment. Data of the Croatian Camping Union show that in 2008 there were 2,466 mobile homes in Croatia, all of which were owned by tour operators (Croatian Camping Union 2008). A study showed that by 2012 there were 2,422 mobile homes owned by campsites and 2,731 mobile homes owned by tour operators, making a total of 5.153 mobile homes (Cvelić-Bonifačić 2012). Data from the Round Table at the Croatian Camping Conference held in Tuhelj 
ToSEE - Tourism in Southern and Eastern Europe, Vol. 5, pp. 457-473, 2019

I. Milohnić, J. Cvelić Bonifačić, I. Licul: TRANSFORMATION OF CAMPING INTO GLAMPING - ...

in November 2018 (Camping HR 2019) reveal there were 11,545 mobile homes and 645 glamping units in Croatia in 2018. The growth rate of the number of mobile accommodation units in Croatian campsites in this six-year period was $237 \%$.

Table 1: Number of mobile homes in Croatia 2008-2018

\begin{tabular}{|c|c|c|c|}
\hline & $\mathbf{2 0 0 8}$ & $\mathbf{2 0 1 2}$ & $\mathbf{2 0 1 8}$ \\
\hline Self-owned mobile homes & - & 3,175 & 7,477 \\
\hline Mobile homes owned by tour operators & 2,466 & 2,588 & 4,068 \\
\hline Total mobile homes & $\mathbf{2 , 4 6 6}$ & $\mathbf{5 , 7 6 3}$ & $\mathbf{1 1 , 5 4 5}$ \\
\hline Glamping accommodation & & & 645 \\
\hline TOTAL & $\mathbf{2 , 4 6 6}$ & $\mathbf{5 , 7 6 3}$ & $\mathbf{1 2 , 1 9 0}$ \\
\hline
\end{tabular}

Source: adapted from: Croatian Camping Union (2008). Business Indicators of the campsites in the Republic of Croatia for 2008. Report; Cvelić-Bonifačić, J. (2012). Menadžment konkurentnosti kamping turizma [Camping Tourism Competitiveness Management] (Doctoral dissertation), University of Rijeka, Faculty of Tourism and Hospitality Management; Camping HR 2019., Round Table of the $12^{\text {th }}$ Croatian Camping Conference 2018, www.camping.hr

Such exceptional growth is particularly important in the context of the total number of accommodation units in Croatia, amounting to 82,379, which means that in the 10-year period glamping accommodation units accounted for a $14.80 \%$ share in campsites. This rapid growth and speedy transformation has brought about changes in by-laws and legislature. The Strategy of Croatian Tourism Development by 2020 promotes product differentiation, service quality improvement and accommodation diversity (Ministry of Tourism 2013). In 2016 the new Ordinance on the Classification and Categorisation of Hospitality Facilities in the group "Campsites" (Croatian Ministry of Tourism 2016) was adopted in which glamping was defined for the first time. Article 14 of the Ordinance classifies glamping into two categories, glamping equipment and glamping mobile homes, and explains their differences, as follows:

- A glamping mobile home constitutes mobile camping equipment made of solid material, not firmly attached to the ground (can be moved), of an uncommon design or spatially placed in an unusual way (for example, underground, on stilts, in a tree, on water, on a cliff, etc.) with or without a bathroom

- Glamping equipment constitutes movable equipment for camping, not made of or only partially made of solid materials; provides an above-ordinary level of service (for example, a tent with a bathroom) and/or is spatially placed in an unusual way (for example, on stilts, in a tree, on water, on a cliff, etc.).

The above analyses point to a key quandary relating to glamping that refers to the connection between mobile homes and glamping. Initially, the production of mobile homes set off a revolution in campsite accommodation. In campsites, mobile homes were the first luxury accommodation which, though mobile, were in fact immobile; in a technical sense they could be moved about but from the guest's perspective they were permanently immobile and perpetually attached to the same accommodation unit. Mobile homes marked the beginning of the transformation of camping into glamping. The early 2000s saw the rapid growth in campsites of accommodation facilities generally referred to as glamping. Adria (formerly Sun Roller) began to manufacture mobile homes in 2003, only to become one of the most respected manufacturers of mobile homes and 
ToSEE - Tourism in Southern and Eastern Europe, Vol. 5, pp. 457-473, 2019

I. Milohnić, J. Cvelić Bonifačić, I. Licul: TRANSFORMATION OF CAMPING INTO GLAMPING - ...

glamping tents in Europe (Adria Mobile Homes 2019). In 2014, the Croatian company NORD became the first manufacturer of mobile homes in Croatia (Duić 2014). As stated at the 2018 Croatian Camping Conference, both companies produce about 600 accommodation units per year.

In Croatia, mobile homes of increasingly innovative designs are becoming a central new product in campsites; a product that is closely linked to innovativeness and is marketed as glamping accommodation. Previous secondary research has shown, however, that common to all definitions of glamping is the association of glamping to camping and to a specific and, in most cases, mobile accommodation facility in a campsite, expected to provide a level of services higher than that of conventional camping. Similarly, glamping is frequently referred to as a trend that is transforming camping into a superior and more luxurious version. Nevertheless, there is no single definition stating what types of accommodation are considered to be glamping accommodation nor have the shared features of glamping accommodation been identified. For the first time in the history of organised accommodation, there are accommodation units that are not standardised, defined or categorised and there is no consensus among the general public and professionals as to what types of accommodation units belong to glamping. While studies regarding the types of accommodation units in glamping have revealed an entire array of types: all kinds of tents, mobile homes, treehouses, floating houses, cabins, domes, villas, holiday flats, etc., there is no single standard for the equipping and furnishing of these accommodation units.

It is still unclear what types of accommodation units belong to glamping, what the features of such units are and how different stakeholders perceive glamping. In addition, the question arises of whether there is sufficient demand for accommodation units considered to be glamping and how that demand is perceived by diverse groups of stakeholders in the camping business. Another issue is how glamping is defined by managers, by manufacturers and by guests. In the following section, the results of research provide answers to these questions.

\section{RESEARCH METHODOLOGY}

To accomplish the objectives of research, a survey was conducted regarding glamping trends and the prospects of glamping development through the transformation of campsites. For the needs of empirical research, structured questionnaires were designed and adjusted to the three groups of respondents. The sample consisted of respondents from the ranks of camping experts (120 managers of Croatian campsites and 30 renowned manufacturers of camping equipment in Croatia, Slovenia and Italy) and guests in campsites on the Adriatic coast (130 respondents).

The questionnaires targeting campsite managers and camping equipment manufacturers comprised five sets of questions and the questionnaire targeting campsite guests, four. To study glamping trends and development prospects, this paper uses the results of processing four sets of questions posed to campsite managers and camping equipment manufacturers and three sets of questions posed to campsite guests. In addition to a set of questions focused on identification data, multiple-choice questions were used to obtain 
ToSEE - Tourism in Southern and Eastern Europe, Vol. 5, pp. 457-473, 2019

I. Milohnić, J. Cvelić Bonifačić, I. Licul: TRANSFORMATION OF CAMPING INTO GLAMPING - ...

opinions regarding the types and features of glamping accommodation facilities. The set of questions investigating glamping experience was especially adjusted to each target group and contained dichotomous, open-ended and multiple-choice questions. To enable campsite managers and glamping equipment manufacturers to rate trends in the context of glamping, a set of questions with a Likert scale, ranging from 1 - strongly disagree to 5 - strongly agree, was designed. The questionnaire targeting campsite managers was filled out by other campsite employees as well.

Data regarding camping experts were collected by the survey method in October 2017 and data regarding glamping guests, by field and online surveys from June to September 2018. IBM SPSS Statistics 23 software was used to process data by means of the appropriate statistical procedures for analysis.

\section{RESEARCH RESULTS}

The results of descriptive statistics are presented as part of the Author's research. A description of the sample is provided, followed by an analysis of opinions regarding types of glamping accommodation facilities. The next section presents the results of questions concerning glamping experience. Finally, the rating of trends in the context of glamping according to the opinions of experts (campsite managers and camping equipment manufacturers) is presented.

The survey included 120 campsite managers at various management levels. The largest share of respondents holds university degrees $(60 \%)$.

The survey also encompassed 30 producers of camping equipment, representing $90 \%$ of all producers in Croatia, including the representatives of the largest Slovenian producer and two Italian producers in Croatia (Croatian Camping Union 2017). Most of them produce mobile homes, a smaller portion produces glamping tents while the smallest portion produces camping equipment.

The study also included a target group of respondents made up of campsite guests. Table 2 presents the socio-demographic structure of campsite guests.

Table 2: Socio-demographic structure of campsite guests

\begin{tabular}{|c|c|c|c|c|c|}
\hline Gender & Share $(\%)$ & Qualifications & Share $(\%)$ & \multirow{2}{*}{$\begin{array}{c}\text { Monthly income } \\
\text { in } €\end{array}$} & \multirow{2}{*}{$\begin{array}{c}\text { Share } \\
(\%)\end{array}$} \\
\hline Male & 32.6 & Secondary school & 62.7 & & \\
\hline Female & 67.4 & $\begin{array}{l}\text { Undergraduate } \\
\text { studies }\end{array}$ & 18.6 & \multirow{2}{*}{ Less than 1000} & \multirow{2}{*}{14.3} \\
\hline $\begin{array}{c}\text { Age } \\
\text { group }\end{array}$ & Share $(\%)$ & $\begin{array}{l}\text { Master's } \\
\text { degree/PhD }\end{array}$ & 18.6 & & \\
\hline $18-35$ & 20.0 & Status & Share $(\%)$ & \multirow{2}{*}{1001 to 2000} & \multirow{2}{*}{32.5} \\
\hline $36-45$ & 41.5 & Employed & 87.6 & & \\
\hline $46-55$ & 24.6 & Unemployed & 1.6 & \multirow{2}{*}{2001 to 5000} & \multirow{2}{*}{45.2} \\
\hline $56-65$ & 10.0 & Pupil or student & 1.6 & & \\
\hline+66 & 3.8 & Retired & 9.3 & More than 5000 & 7.9 \\
\hline
\end{tabular}

Source: Author's research 
ToSEE - Tourism in Southern and Eastern Europe, Vol. 5, pp. 457-473, 2019

I. Milohnić, J. Cvelić Bonifačić, I. Licul: TRANSFORMATION OF CAMPING INTO GLAMPING - ...

The majority of surveyed guests are female (67.4\%), 36 to 45 years old (41.5\%), with secondary school qualifications $(62.7 \%)$, employed $(87.96 \%)$ and with a monthly income from 2001 to $5000 €$. The below graph illustrates the heterogeneity of campsite guests by country from where they are coming.

\section{Graph 2: Country of residence of campsite guests}

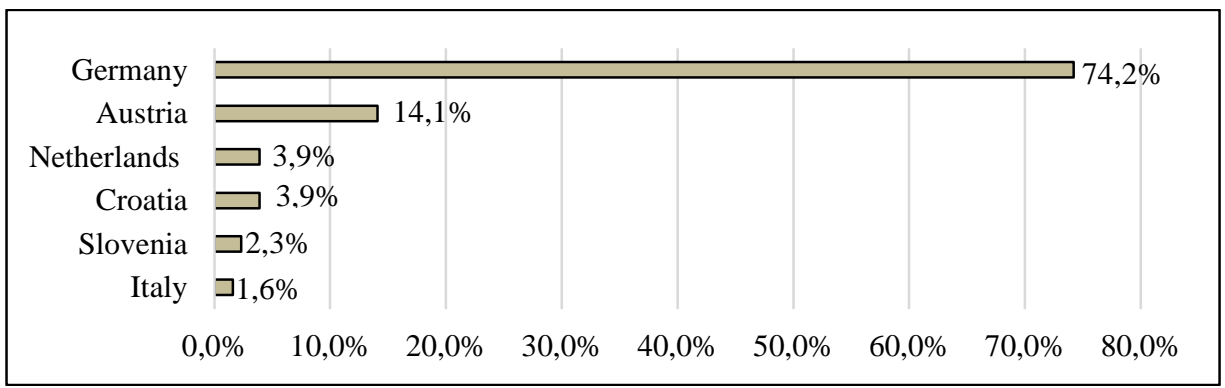

Source: Author's research

The majority of surveyed campsite guests are from Germany (74.2\%), followed by guests from Austria (14.1\%) and guests from the Netherlands and Croatia (each with a share of $3.9 \%)$. The fewest guests are from Slovenia (2.3\%) and Italy (1.6\%).

To further explore the profile of campsite guests, respondents were asked questions concerning previous vacationing, the means of transportation used to come to the campsite, the usage of camping equipment and accommodation, and preferred outdoor activities.

Graph 3: Vacations of campsite guests in previous years

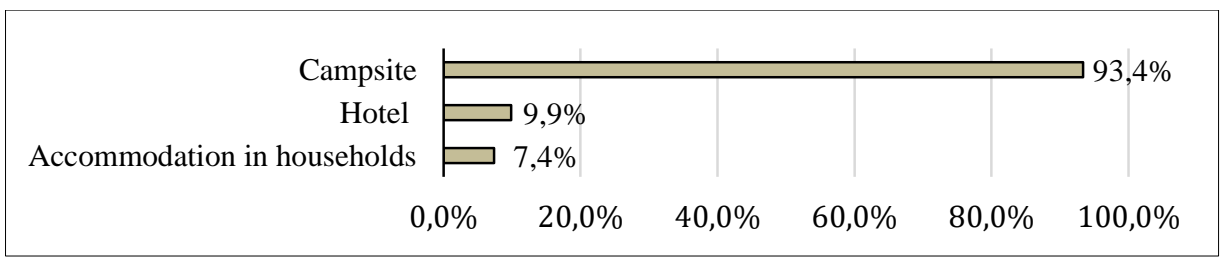

Source: Author's research

The data in the above graph suggest that respondents are strongly loyal to campsites, as most the respondents (93.4\%) have mainly vacationed in campsites in previous years. Only $9.9 \%$ and $7.4 \%$ of respondents have spent their previous vacations in hotels and in accommodation in households, respectively.

The below graph presents the types of transportation means guests used to travel to campsites. 
ToSEE - Tourism in Southern and Eastern Europe, Vol. 5, pp. 457-473, 2019

I. Milohnić, J. Cvelić Bonifačić, I. Licul: TRANSFORMATION OF CAMPING INTO GLAMPING - ...

\section{Graph 4: Types of transportation means used by guests to travel to campsites}

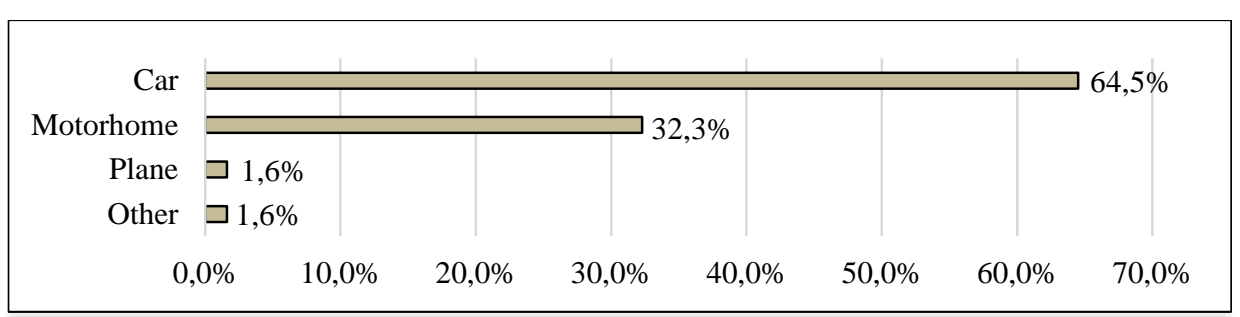

Source: Author's research

Most of the respondents travelled to the campsite by passenger car $(64.5 \%)$ and $32.3 \%$ in their motorhomes. Only $1.6 \%$ of respondents travelled by air or used some other type of transportation.

Interesting results were obtained upon processing data obtained from questions regarding the use of camping equipment/accommodation.

\section{Graph 5: Use of camping equipment}

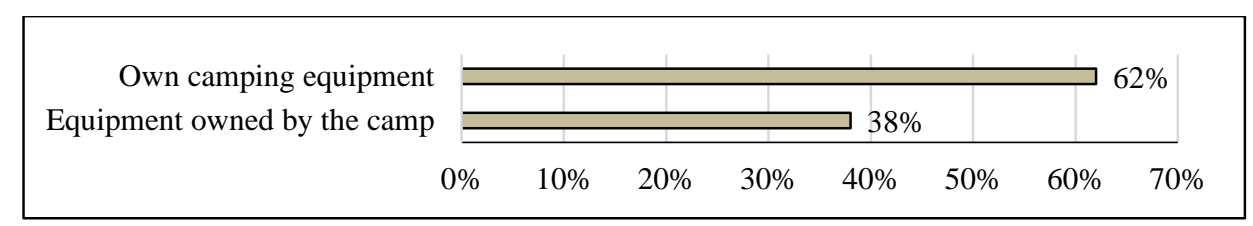

Source: Author's research

Fully $62 \%$ of respondents reported that they came to the campsite with their own camping equipment and/or accommodation while $38 \%$ of respondents came with the intention of using accommodation owned by the camp. The latter percentage corresponds to the total share of mobile homes allowed in campsites, which is $40 \%$.

The survey continued by asking campsite guests to report their degree of preference for outdoor activities.

\section{Graph 6: Campsite guests' degree of preference for outdoor activities}

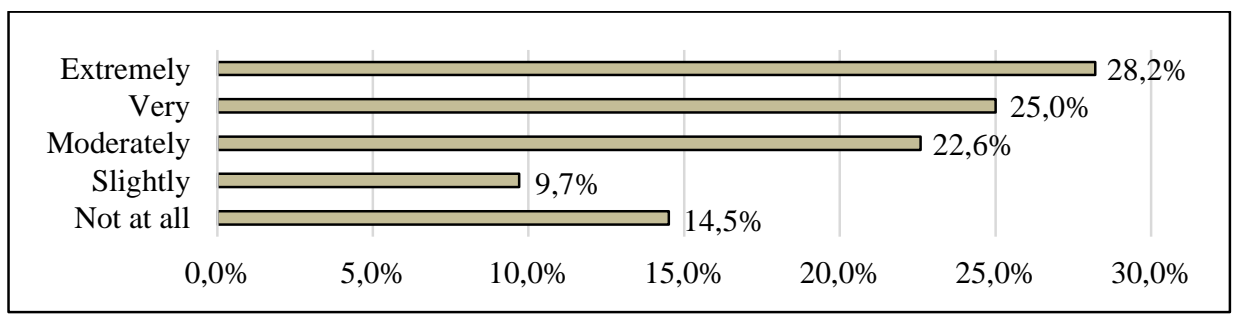

Source: Author's research 
ToSEE - Tourism in Southern and Eastern Europe, Vol. 5, pp. 457-473, 2019

I. Milohnić, J. Cvelić Bonifačić, I. Licul: TRANSFORMATION OF CAMPING INTO GLAMPING - ...

Two thirds of respondents $(75.8 \%)$ expressed a high degree of preference for outdoor activities $(28.2 \%$ of respondents extremely prefer them; $25 \%$, very much prefer them; and $22.6 \%$, moderately prefer them). In general, the survey campsite guests rated outdoor activities with an average score of 3.43 . This finding suggests there is a strong relationship between glamping and outdoor activities in campsites.

Half of the surveyed campsite guests $(51 \%)$ stated that up to date they have used some of the innovative forms of accommodation during their stay at the campsite.

To investigate in-depth, the opinions of respondents regarding types of glamping facilities, the respondents in all three target groups were asked to choose, out of the listed types of accommodation, the types they consider to be glamping accommodation facilities. The options they could choose from included treehouses, bungalows, caravans, cabins, floating homes, fully equipped (safari) tents, fully equipped mobile homes, unusual types of accommodation (barrels, wooden tents, circus wagons, geodomes, etc.) and other types of accommodation. The results of research are presented below.

\section{Graph 7: Types of glamping accommodation facilities}

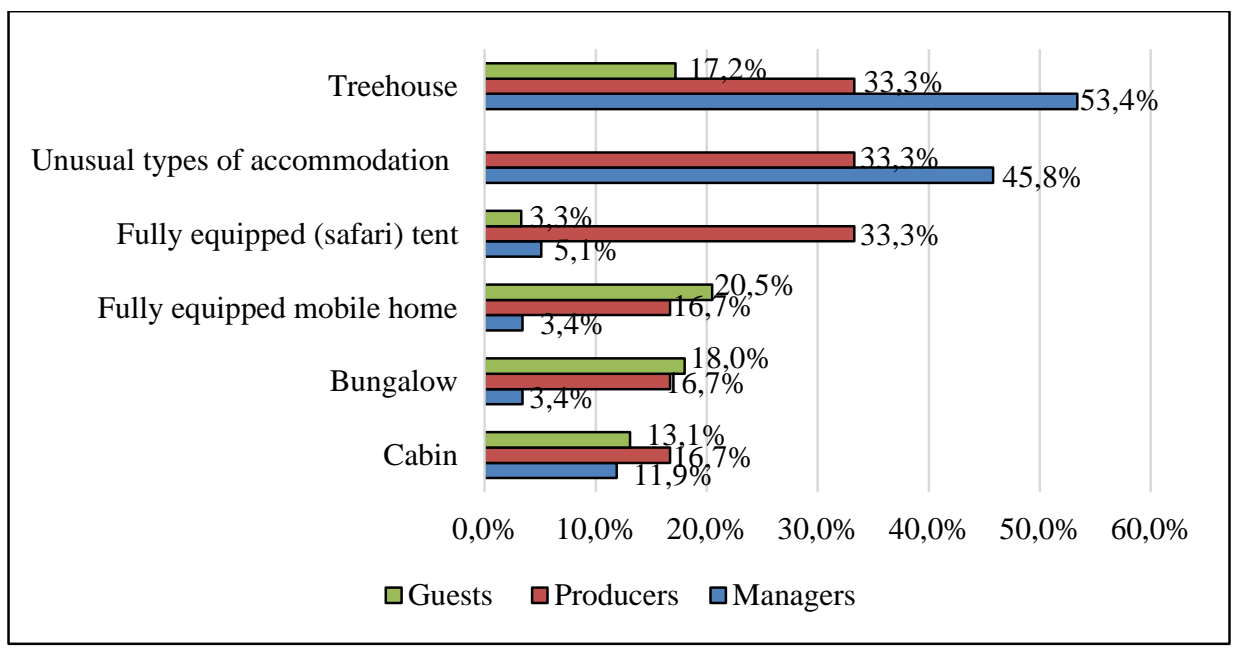

Source: Author's research

The results in Graph 7 suggest there are certain differences in opinions concerning types of glamping facilities among the three surveyed groups of respondents. Most campsite managers $(53.4 \%)$ and $33.3 \%$ of equipment manufacturers consider a treehouse as being a glamping accommodation facility, while $45.8 \%$ of campsite managers and $33.3 \%$ of equipment manufacturers opted for unusual types of accommodation. Interestingly, campsite guests do not consider either of these two types of accommodations as being glamping accommodation. On the other hand, while the largest share of campsite guests $(20.5 \%)$ sees fully equipped mobile homes as being glamping accommodation, only $16.7 \%$ of equipment manufacturers and $3.4 \%$ of managers were of the same opinion. 
ToSEE - Tourism in Southern and Eastern Europe, Vol. 5, pp. 457-473, 2019

I. Milohnić, J. Cvelić Bonifačić, I. Licul: TRANSFORMATION OF CAMPING INTO GLAMPING - ...

The largest differences in perceiving glamping accommodation facilities are obvious in the case of fully equipped (safari) tents, which $33.3 \%$ of equipment manufactures - but only $5.1 \%$ of campsite managers and $3.3 \%$ of campsite guests - consider to be glamping accommodation.

Respondents in all three target groups were then asked to choose, from a list of characteristics, those that pertain to glamping accommodation facilities. Respondents were asked to choose from the following characteristics: top-level equipment and amenities, top-quality service (bed linen changes, bell-boy services, cleaning services, beauty salon services, etc.), location in a natural environment, any type of mobile home, and other attributes. "A mobile home is not a glamping accommodation" was also one of the options listed.

\section{Graph 8: Characteristics of glamping accommodation facilities}

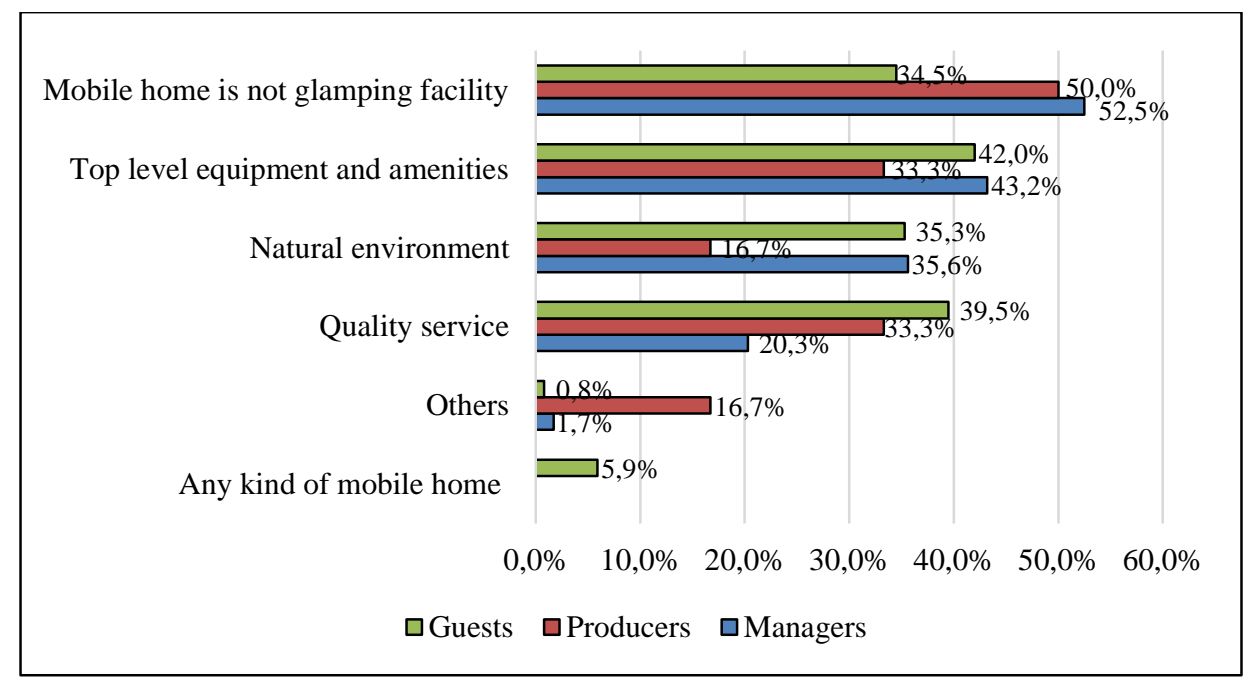

Source: Author's research

The surveyed groups of respondents showed markedly different opinions with regard to the perception of glamping accommodation characteristics. Half of the surveyed managers $(52.5 \%)$ and camping equipment manufacturers (50\%) and $34.5 \%$ of campsite guests do not consider that mobile homes are glamping accommodations. Contrarily, all three target groups ( $42 \%$ of campsite guests, $43.2 \%$ of campsite mangers and $3.3 \%$ of camping equipment manufacturers) singled out "Top level equipment and amenities" as an attribute of glamping facilities. Furthermore "Quality service" was a glamping facility characteristic chosen by $39.5 \%$ of guests, $33.3 \%$ of equipment manufacturers and $20.3 \%$ of managers. The largest deviations in the perception of glamping facility characteristics were noted with regard to "Natural environment", a characteristic selected by only $16.7 \%$ of equipment manufacturers but also by many campsite managers $(35.6 \%)$ and campsite guests $(35.3 \%)$. Only $5.9 \%$ of campsite guests consider any type of mobile home as being a glamping facility. 
ToSEE - Tourism in Southern and Eastern Europe, Vol. 5, pp. 457-473, 2019

I. Milohnić, J. Cvelić Bonifačić, I. Licul: TRANSFORMATION OF CAMPING INTO GLAMPING - ...

Glamping experience was investigated using sets of questions specially adjusted to each target group. Campsite managers were asked to state which campsite guest target group shows the most significant changes in demand for new forms of accommodation.

Graph 9: Guest generations with changes in demand for new forms of accommodation, according to the opinion of campsite managers

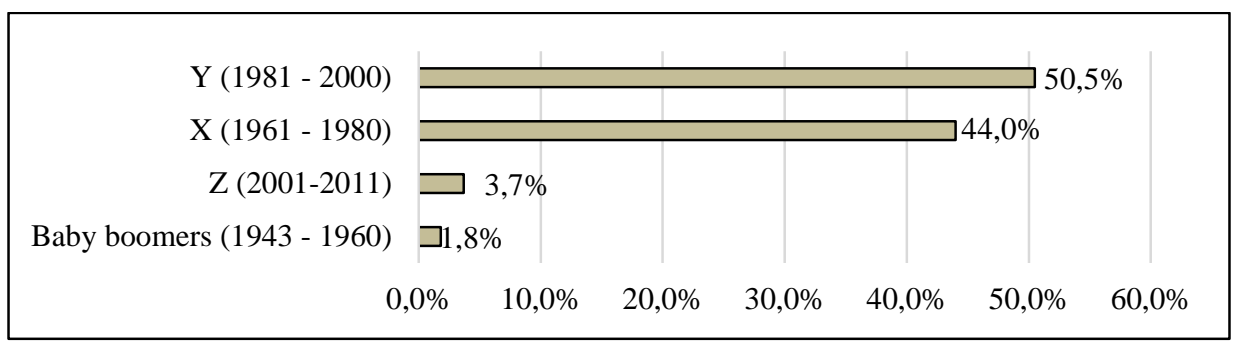

Source: Author's research

More than half of the campsite managers $(50.5 \%)$ believe that Generation Y shows the most significant change in demand for new forms of accommodation, while fully $44 \%$ believe it is Generation X. These results are consistent with the target group of respondents in the sample made up of campsite guests, considering that most of them $(66.1 \%)$ belong to Generation $\mathrm{X}$ and $20 \%$, to Generation Y.

In this set of questions, interesting results were obtained when processing the question targeting campsite guests, asking them whether they plan to use glamping accommodation in the future. Fully $44.6 \%$ of surveyed guests gave an affirmative reply to the question, indicating that most campsite guests still remain loyal to their own camping equipment and that staying in glamping accommodation in a campsite is increasingly being equated with so-called classical camping. All surveyed campsite managers $(100 \%)$ and $63 \%$ of surveyed campsite guests consider that the introduction of innovative forms of accommodation contributes towards enhancing the competitiveness of a campsite.

The results of the conducted research point to substantial differences in opinions regarding glamping and its characteristics. Differences in understanding the term "glamping" are particularly evident in the group of surveyed campsite guests relative to the other groups of respondents.

In another set of questions, campsite managers and campsite equipment manufacturers were asked to use a Likert scale to rate statements pertaining to trends in glamping. Campsite managers were asked to rate five statements and campsite equipment manufacturers, two statements. Results are presented in the below table. 
ToSEE - Tourism in Southern and Eastern Europe, Vol. 5, pp. 457-473, 2019

I. Milohnić, J. Cvelić Bonifačić, I. Licul: TRANSFORMATION OF CAMPING INTO GLAMPING - ...

Table 3: Trends in glamping according to campsite managers and campsite equipment manufacturers

\begin{tabular}{|c|l|c|c|c|c|}
\hline \multirow{2}{*}{ No. } & \multicolumn{1}{|c|}{ Statements SD } & \multicolumn{2}{|c|}{ Managers } & MEAN & SD \\
\cline { 2 - 6 } 1 & $\begin{array}{l}\text { Today there is an upward trend in } \\
\text { campers using accommodation in } \\
\text { campsites rather than their own } \\
\text { camping equipment. }\end{array}$ & $\mathbf{4 . 0 8}$ & 1.042 & $\mathbf{4 . 1 7}$ & .913 \\
\hline 2 & $\begin{array}{l}\text { The development of innovative forms } \\
\text { of accommodation is a trend in } \\
\text { campsite accommodation. }\end{array}$ & $\mathbf{4 . 4 7}$ & .594 & $\mathbf{4 . 8 3}$ & .379 \\
\hline 3 & $\begin{array}{l}\text { Innovative accommodation in } \\
\text { campsites helps to attract guests to a } \\
\text { campsite from other types of } \\
\text { accommodation (hotels, holiday flats) }\end{array}$ & $\mathbf{4 . 3 7}$ & .898 & $/$ & $/$ \\
\hline 4 & $\begin{array}{l}\text { Innovative accommodation in } \\
\text { campsites helps to attract guests } \\
\text { travelling by air. }\end{array}$ & $\mathbf{3 . 8 7}$ & .940 & / & / \\
\hline 5 & $\begin{array}{l}\text { Innovative accommodation in } \\
\text { campsites helps to attract guests who } \\
\text { have a preference for outdoor activities } \\
\text { in campsites. }\end{array}$ & $\mathbf{4 . 2 3}$ & .930 & / \\
\hline
\end{tabular}

Source: Author's research

Respondents gave high average scores to all statements. Managers gave the highest average score (4.47) to the statement "The development of innovative forms of accommodation is a trend in campsite accommodation". The score given to the same statement by campsite equipment manufacturers was 4.83 . Campsite managers gave the lowest average score (3.87) to the statement "Innovative accommodation in campsites helps to attract to guests travelling by air".

\section{CONCLUSION}

Glamping, a trend of neo-comfort, argues strongly in favour of putting camping back in the focus of tourism interests through a novel, luxurious form of camping; in the market it plays the role of the new champion and powerful promotor of innovative camping tourism that is adjusted to new generations and environmentally sensitive. The study shows that the opinions of managers, manufacturers and guests differ with regard to the type of accommodation facility called glamping. To guests glamping also implies a stay in a mobile home, contrary to the opinions of managers and manufacturers. Most respondents agree with the statement that glamping is connected with a number of innovative types of accommodation.

In researching trends in the transformation of campsites, a key fact is that more than two thirds of respondents engage in outdoor activities that range from moderate to extreme. Although most guests still use their own camping equipment (they arrive in their own caravans or campervans), more than half of the respondents have previously stayed in some innovative type of accommodation and almost one half (44.6\%) believe they will 
ToSEE - Tourism in Southern and Eastern Europe, Vol. 5, pp. 457-473, 2019

I. Milohnić, J. Cvelić Bonifačić, I. Licul: TRANSFORMATION OF CAMPING INTO GLAMPING - ...

stay in a glamping facility in the future. This indicative fact is especially important considering that the survey was conducted among existing campsite guests, some of which are strongly loyal to camping. The fact that almost half of surveyed campsite guests and most of the surveyed campsite managers consider they will use glamping accommodation as a strategic guideline for the continued transformation of camping into glamping. The study also indicates that a part of the campers will continue to use their own camping equipment and that glamping at present is not yet the prevailing form of accommodation in campsites. Manufacturers and managers think that in campsites there is an upward trend in the use of campsite accommodation relative to the use of the campers' own equipment. Campsite guests also believe there is such a trend, although they do not see the transformation of accommodation happening at the brisk pace suggested by managers and manufacturers.

The opinions of all groups of respondents are the same, however, where the characteristics of glamping accommodation are concerned. All respondents share the opinion that glamping accommodation implies top-quality equipment and services, that the natural environment is a key characteristic of glamping and that service quality is indisputable. Research results suggest that while there is still no clear-cut definition for the types of accommodation units referred to as glamping, the unambiguous characteristics of glamping include the natural environment and the quality of equipment and services. Results also indicate that camping is transforming through innovative forms of accommodation. This transformation is not far-fetched, however, because the ratio of classical camping to camping in innovative accommodation units is 60:40 at present. The study also shows that guests consider mobile homes to be glamping accommodation providing they meet the earlier stated criteria of equipment, accommodation and service quality. It follows from the research that glamping could play a decisive role in rekindling the appeal and attraction of camping. Glamping is expected to attract guests who love nature but want to stay in a more comfortable accommodation with top-quality service. The future development of the market of accommodation units in camps is expected to focus on innovative accommodation. A change is taking place in the structure of camping facilities in favour of a larger number of accommodation units offered by campsites relative to the number of accommodation units foreseen for guests arriving with the own camping equipment. Innovative camping managers need to manage change in the camping product; this involves ensuring a well-designed mix of accommodation units in a campsite and selecting innovative accommodation units for the campsite.

Based on the conducted study, proposals can be put forward for the benefit of future researchers. Considering that respondents in the group of guests were German nationals and existing guests in campsites, it is advisable to include other nationalities as respondents as well as guests staying in hotels, B\&Bs, holiday flats and rooms. It is also recommended for future studies to investigate in particular the opinions of guests who have already stayed in some form of glamping accommodation. 
ToSEE - Tourism in Southern and Eastern Europe, Vol. 5, pp. 457-473, 2019

I. Milohnić, J. Cvelić Bonifačić, I. Licul: TRANSFORMATION OF CAMPING INTO GLAMPING - ...

\section{ACKNOWLEDGEMENT}

This paper is an output of the science project Glamping - a Factor of Campsite Quality. This research has been financially supported by the University of Rijeka, for the projects ZP UNIRI 5/17.

\section{REFERENCES}

Allgemeine Deutsche Automobil-Club ADAC Medien und Reise GMBH, Muenchen n.d., viewed 1 February 2019, https://media.adac.de/start/uebersicht/

Adria Mobile Homes, About Adria: History n.d., viewed 15 January 2019, https://www.adria-mobilehome.com/en/about-adria\#history

American Camper Report (2014), Wichita, The Coleman Company, INc Outdoor Foundation. Viewed 1 January 2019, https://outdoorindustry.org/wp-content/uploads/2017/05/2014-Camping-ReportFINAL.pdf

American Glamping Association. About Association n.d., viewed 22 January 2019 https://americanglampingassociation.net/about/

Avtokampi.si - Rad kampiram - Informacije o kampih, Herbal glamping resort Ljubno, Viewed 28 January 2018, www.avtokampi.si.

Booking.com (1996-2019), Glamping in UK, viewed 2 February 2019 , https://www.booking.com/glamping/country/gb.en-gb.html

Brooker, E., and Joppe, M. (2013), "Trends in camping and outdoor hospitality - An international review", Journal of outdoor Recreation and Tourism, Vol. 3, pp. 1-6. https://doi.org/10.1016/j.jort.2013.04.005

Camping HR, Okrugli stol 12. kongresa hrvatskog kampinga 2018., viewed 8 February 2019, www.camping.hr

Carter, G. (2011), "Enterpreneur Europe“ Camping's Extreme Makeover", Viewed 22 January 2019, https://www.entrepreneur.com/article/220037

Charming Slovenia n.d., viewed 15 February 2018 http://www.charmingslovenia.com/en/

Chateau Ramšak, Vineyard Glamping Resort n.d., viewed 25 January 2018, https://www.chateauramsak.com/

Colin, J. (2008), “Camping? Yes. Roughing it? Not Quite”, New York Times, Viewed 17. February 2019, www.nytimes.com/2008/09/14/travel/14green-1.html? r=0

Cvelić-Bonifačić, J. (2012), Menadžment konkurentnosti kamping turizma (Doctoral dissertation), Sveučilište u Rijeci, Fakultet za menadžment u turizmu i ugostiteljstvu.

Croatian Camping Union (2008), Business Indicators of the campsites in the Republic of Croatia for 2008 , Report.

Croatian Camping Union (2017), 11th Croatian Camping Congress, 13th - 15th November 2017 https://www.camping.hr/news

Deutsche Digitale Woertersbuch DWDS n.d., viewed 24 January 2019 https://www.dwds.de/wb/Glamping

Garden Village Bled, Glamping Accommodation n.d., viewed 18 January 2018, https://gardenvillagebled.com/en/accommodation/glamping_tents

Glamping Association n.d., viewed 30 January 2018, www.glampingassociation.co.uk/history of glamping.php

Glamping Europa n.d., viewed 3 January 2019, www.glampingeuropa.de: https://www.glampingeuropa.de/

Glamping Hub (2012), January 17). viewed 2 May 2018 www.glampinghub.com: https://glampinghub.com/whats-glamping/

Glamping.com. n.d., viewed 7 February 2019, www.glamping.com: https://www.glamping.com/about/ . G

Glampings. n.d., viewed 19 January 2019, https://glampings.de/blog/was-ist-glamping\%20

Google Search. Glamping 2018. viewed 5 January 2019, https://trends.google.com/trends/explore?date=all\&q=glamping

Haak, E. (2011), “The Rise of Glamping: Glamorous Camping," Fastcompany, viewed 12 November 2017, https://fastcompany.com/1752600/rise-glamping-glamorous-camping

Inspired Camping (2017), viewed 18 January 2019, https://www.inspiredcamping.com/

Inspired Camping. (2018), Glamping business start up guide, viewed 14 January 2019, https://www.inspiredcoursesvip.com/glamping-business-start-up-guide

Kampgrounds of America KOA n.d. Unique accommodation viewed 14 January 2019 https://koa.com/waysto-stay/unique-accommodations/

Kampgrounds of America KOA n.d. North American Camper Report, viewed 15 February 2017, https://koa.com/north-american-camping-report/ 
ToSEE - Tourism in Southern and Eastern Europe, Vol. 5, pp. 457-473, 2019 I. Milohnić, J. Cvelić Bonifačić, I. Licul: TRANSFORMATION OF CAMPING INTO GLAMPING - ...

Kampgrounds of America KOA n.d., The 2018 Nord America Campng Report, viewed 15 January 2019 ttps://koa.com/north-american-camping-report/\#lp-findings

Križaj, D. and Zakonjšek, T.H. (2011), "National mechanism for spurring innovation in Slovenian tourism", Academica Turistica, Vol. 1, pp. 103-110.

Leading camping Europe, Wonderful campsites around Europe, n.d., viewed 11 February 2018, https://www.leadingcampings.com/en/campsites.html

Leci Sakačova, K. (2013), Glamping - Nature served on silver platter, Master's thesis, Aalborg University, viewed 21 January 2019, https://projekter.aau.dk/projekter/files/76860450/Glamping.pdf

Lohman, M., Schmucker, D., and Sonntag, U. (2017), "Urlaubstrends 2017. Kiel: Forshunggemeinschaft Urlaub und Reisen e.V.”, Reiseanalyse. Viewed 2. January 2017, https://reiseanalyse.de/

Ministarstvo turizma, Republike Hrvatske (2013), Strategija razvoja turizma Republike Hrvatske do 2020. Godine, Narodne novine 55/13, Zagreb, Hrvatska: Narodne novine.

Ministarstvo turizma Republike Hrvatske (2016), Pravilnik o razvrstaniju i kategorizaciji ugostiteljskih objekata iz skupine kampovi, Narodne novine 54/16, Narodne novine. https://narodne-novine.nn.hr/clanci/sluzbeni/2016_06_54_1409.html

Oxford Dictionary, Glamping, n.d., viewed 7 January 2019, http://www.oxforddictionaries.com/definition/english/glamping)

Duić, M. (2014), “Mobilnim kućicama osvajaju tržište Europske unije i Indije”, Poslovni Hr., viewed 27 January 2019, http://www.poslovni.hr/poduzetnik/mobilnim-kucicama-osvajaju-trziste-europskeunije-i-indije-291787/

Rogers, K. (2011), "Fox Business: Glamping - Where Nature meets Luxury”, Fox News Network, viewed 28 January, 2019, https://www.foxbusiness.com/features/glamping-where-nature-meets-luxury

Suncamp Holidays. (2019), viewed 2 February 2019, www.suncamp.de: https://www.suncamp.de/thema/glamping/29/? ga=2.125329034.1835976882.1551603905 $853679635.1551603905 \#$ fq=duration $\% 3 \mathrm{~A} 7 \& \mathrm{fq}=$ themes $\% 3 \mathrm{~A} 29 \&$ rows $=6$

Terme Olimia, Glamping Olimia Adria Village, n.d., viewed 25 January 2018 , http://www.terme-olimia.com/gb/hotels/glamping-olimia-17997

The Guardian (2010), Carry on glamping: Europe's poshest, coolest camping experiences, viewed 25 February 2017, https://www.theguardian .com/travel/2010/may/15/glamping-camping-europe-yurt-tipi

Vacansselect, Glamouröses und luxuriöses Camping n.d., viwes 13 January 2018, https://www.vacanceselect.com/de/urlaubsideen/glamping

World Toddler. (2016), The History of glamping, viewed 28 January 2018 , http://www.worldtoddler.com/2016/02/the-history-of-glamping.html

Zwingenberger, O. (2017), Trend research: 2017 Travel market, Muenchen: ADAC Reise - Monitor, ADAC Verlag Anzeigenmarketing.

Ines Milohnić, PhD, Full Professor

University of Rijeka, Faculty of Tourism and Hospitality Management

Department of Management

Primorska 42, 51410 Opatija, Croatia

Phone: +385-51-294692

E-mail: ines.milohnic@fthm.hr

Josipa Cvelić Bonifačić, PhD, Assistant Professor

University of Rijeka, Faculty of Tourism and Hospitality Management

Primorska 42, 51410 Opatija, Croatia

Phone: +385-51-294692

E-mail: josipa.bonifacic@fthm.hr

Ivana Licul, MA, Assistant

University of Rijeka, Faculty of Tourism and Hospitality Management

Department of Management

Primorska 42, 51410 Opatija, Croatia

Phone: +385-51-294181

E-mail: ivana.licul@fthm.hr 